\title{
Health and Environmental Impacts of Smoke from Vegetation Fires: A Review
}

\author{
Zifei Liu', James Pat Murphy', Ronaldo Maghirang1, Daniel Devlin² \\ ${ }^{1}$ Department of Biological \& Agricultural Engineering, Kansas State University, Manhattan, KS, USA \\ ${ }^{2}$ Department of Agronomy, Kansas State University, Manhattan, KS, USA \\ Email: zifeiliu@ksu.edu
}

How to cite this paper: Liu, Z.F., Murphy, J.P., Maghirang, R. and Devlin, D. (2016) Health and Environmental Impacts of Smoke from Vegetation Fires: A Review. Journal of Environmental Protection, 7, 1860-1885. http://dx.doi.org/10.4236/jep.2016.712148

Received: October 21, 2016

Accepted: November 22, 2016

Published: November 25, 2016

Copyright $\odot 2016$ by authors and Scientific Research Publishing Inc. This work is licensed under the Creative Commons Attribution International License (CC BY 4.0).

http://creativecommons.org/licenses/by/4.0/

\begin{abstract}
Smoke exposure is often an inevitable side effect of open vegetation fires (both planned and wild) and is an important public health concern. The objective of this paper is to summarize state-of-the-art knowledge on health and environmental impacts of smoke from vegetation fires, to identify research gaps, and to provide needed information to researchers, land managers, policymakers, health care workers, and the general public. The main components of vegetation fire smoke and their characterizations are identified and evaluated. Concentrations, emission ratios, and emission factors of smoke components and the combined health and environmental effects of all hazardous smoke components from vegetation fire smoke exposure are summarized. Trends in risk assessment of vegetation fire smoke, limitations of current research, and future research needs are discussed.
\end{abstract}

\section{Keywords}

Emission, Exposure, Epidemiology, Prescribed Burning, Particulate Matter, Air Pollution

\section{Introduction}

Vegetation fires, both planned and wild, usually include grassland, forest, and agricultural crop residues. Smoke exposure is often an inevitable side effect of open vegetation fires and is an important public health concern. Smoke also contributes to regional haze and changes the reflective albedo of the atmosphere, thus affecting climate [1]. Current knowledge of the health impacts of particulate matter (PM) in the air comes mainly from epidemiology studies of urban pollution; however, combustion-derived aerosols in vegetation fire smoke usually differ markedly from urban aerosols in their constituents and characterizations, and thus can have different toxicological effects. In a study 
of wildfires in California, Wegesser et al. [2] found that PM under the influence of fires was about 10 times more damaging to alveolar macrophages than PM collected under normal conditions on an equal-dose basis; therefore, simply extrapolating findings on health impacts of urban pollution to fire smoke pollution may be inappropriate [3]. The number of studies on smoke from vegetation fires and its impacts is relatively small due to inherent difficulties in field measurement [4], the uncertainties of scaling from laboratory experiments to real open fires [5], and the lack of appropriate individual health data associated with fire events [3]. Scientific information on characterization of smoke components, levels of exposure, and their associated health and environmental impacts has not been readily accessible. The objectives of this paper are to summarize state-of-the-art knowledge of the health and environmental impacts of smoke from vegetation fires, identify research gaps, and provide needed information to researchers, land managers, policymakers, health care providers, and general public.

\section{Conditions of Combustion and Production of Smoke}

Characterization of fire smoke depends on the chemical composition of the fuel and combustion conditions. Vegetation fuels may consist of celluloses, hemicelluloses, lignins, proteins, amino acids, and other metabolites, including volatile substances (alcohols, aldehydes, terpenes, etc.), minerals, and water, with the typical carbon content ranging from $37 \%-54 \%$ [6]. Smoke compounds from vegetation fires contain mainly carbon, oxygen, and hydrogen, which are predominantly a function of combustion conditions. Combustion conditions determine efficiency and products of combustion. In complete or highly efficient combustion, the fuel burns oxygen $\left(\mathrm{O}_{2}\right)$ and primarily yields carbon dioxide $\left(\mathrm{CO}_{2}\right)$ and water. Combustion efficiency can be evaluated using the ratio of carbon released as $\mathrm{CO}_{2}$ over total carbon. The two main factors directly affecting combustion efficiency are combustion temperature and availability of $\mathrm{O}_{2}$ [7] (Figure 1). The combustion temperature depends on air and fuel temperature as well as fuel properties such as the heating value and the specific heat capacity, and it determines the molecular alteration and transformation of emitted organic compounds [1]. Availability of $\mathrm{O}_{2}$ depends on wind, turbulence, and characteristics of the fuel, such as vegetation density, shape, and structure [8]. When fuels are heated to the ignition point, flaming occurs; temperatures in this phase range from $325^{\circ} \mathrm{C}$ to $350^{\circ} \mathrm{C}$ [9]. Hot flaming fires produce more nitrogen oxides $\left(\mathrm{NO}_{\mathrm{x}}\right)$, but less carbon monoxide $(\mathrm{CO})$, unburned hydrocarbons, and PM than non-flaming fires [5]. Flaming combustion with sufficient $\mathrm{O}_{2}$ is highly efficient and usually results in minimal smoke and toxic compounds. Flaming combustion in a low- $\mathrm{O}_{2}$ environment leads to high yields of $\mathrm{CO}$ and smoke [7]. Tewarson et al. [10] found smoke generation increased by up to 2.8 times under ventilation-controlled conditions. On the other hand, when temperatures are below the auto-ignition temperature, pyrolysis occurs in the absence of flaming. This lower-temperature process $\left(200^{\circ} \mathrm{C}-300^{\circ} \mathrm{C}\right)$ produces a much greater quantity of incompletely oxidized pyrolysis products including $\mathrm{PM}, \mathrm{CO}$, and other toxic products than flaming combustion [11] [12]. Anaerobic pyrolysis may yield even more toxic 


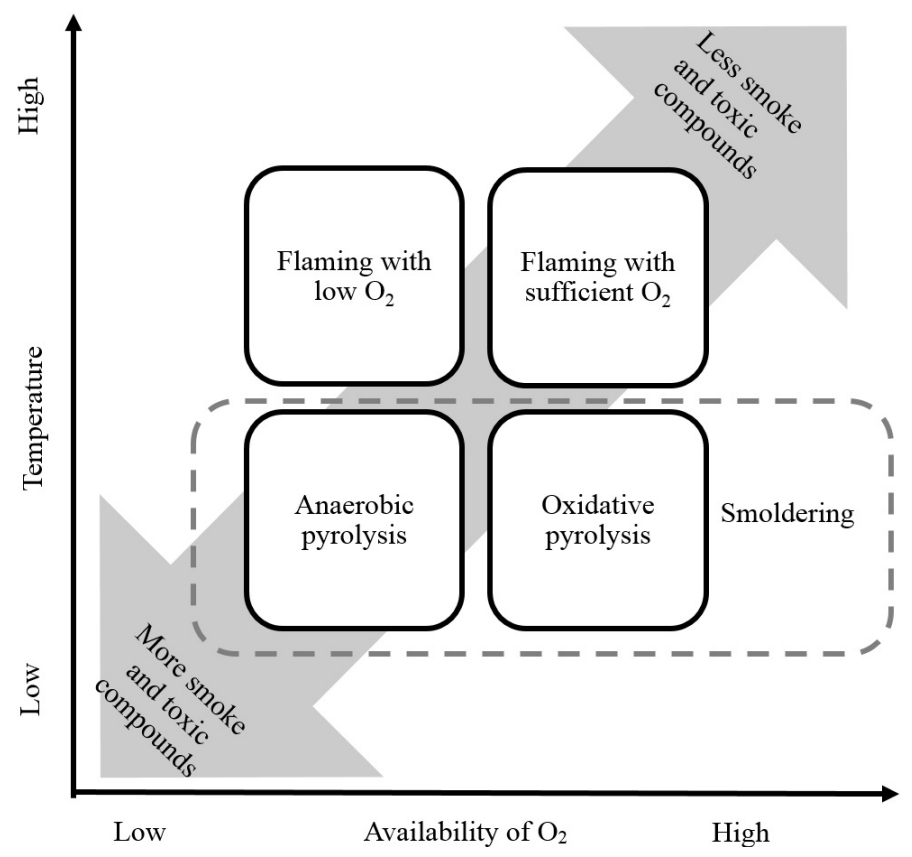

Figure 1. Conditions of combustion and production of smoke.

compounds than oxidative pyrolysis due to further limitation of $\mathrm{O}_{2}$ [7]. Both oxidative and anaerobic pyrolysis (non-flaming fires) are commonly described as smoldering [13]. Emissions of PM during smoldering conditions can more than double emissions under flaming conditions [9] [14], and emissions of polycyclic aromatic hydrocarbons (PAHs), organic carbon (OC), elemental carbon (EC), etc., are characteristic of smoldering, low-intensity burns [15]. Incomplete combustion due to low temperatures and a low- $\mathrm{O}_{2}$ environment result in the greatest quantities of smoke and toxic compounds.

In open vegetation fires, a moving fire front passes through a fuel bed, such as a grassland or forest [6]. Different combustion conditions may occur simultaneously at different locations within the fire environment [7]. Their proportions and the prevalent conditions vary over time, typically with more flaming in the earlier part of the fire and more smoldering during the latter part [6]. The overall mixture of combustion products is usually determined by the amount of smoldering combustion, which is affected by fuel properties. The moisture content of vegetation fuel, for example, varies considerably and can affect production of smoke by influencing temperature and availability of $\mathrm{O}_{2}$. When the moisture content is too high, an appreciable amount of energy is necessary to vaporize the water. Water vaporization lowers temperature, which favors smoldering and increased smoke formation [16]. On the other hand, vegetation with lower moisture content burns faster, eventually causing $\mathrm{O}_{2}$-limited conditions that also lead to increased smoke formation [1]. Core et al. [16] [17] found the optimal moisture content in terms of minimizing PM emissions is $20 \%-30 \%$ for wood combustion.

\section{Main Components of Vegetation Fire Smoke}

Vegetation fire smoke is a complex mixture of airborne solid and liquid PM, vapors, 
and gases, which can contain thousands of individual compounds with a huge range of chemicals in categories such as PM, volatile and semi-volatile organic compounds (VOCs and SVOCs), inorganic gases, and water vapor [8] [18] [19] (Table 1). Various chemicals are produced by incomplete burning of carbon-containing materials and depend on the nature of the fire and the combustion conditions [7] [20] [21] [22]. Despite some commonalities, fires can be significantly different from each other, and each fire may ultimately need to be considered individually for their characteristics.

\subsection{PM}

PM is the solid or liquid component of smoke, which is highly visible and is the principal public health concern from smoke exposure. The main compositions in PM include elemental carbon (EC, also known as soot or black carbon, 2\% - 20\% of PM mass) [22] [23], organic carbon (OC, 60\% - 70\% of PM mass [24], and inorganic ash [22] [24]. EC are primary particles that form as a result of incomplete combustion of carbon-based

Table 1. Summary of main components in vegetation fire smoke.

\begin{tabular}{|c|c|c|c|}
\hline Category & Components & Characterization & Health and environmental impacts \\
\hline \multirow{4}{*}{ Particles } & $\mathrm{PM}$ & $\begin{array}{l}\text { Complex mixtures of EC, } \mathrm{OC} \text { and } \\
\text { inorganic ash; } 70 \%-90 \% \text { of } \mathrm{PM} \text { is } \mathrm{PM}_{2.5} \\
\text { can be transported over long distances. }\end{array}$ & $\begin{array}{l}\text { Act as vehicles to carry absorbed hazardous compounds into the respiratory tract; } \\
\text { increases respiratory and cardiovascular mortality and morbidity, including } \\
\text { asthma and emphysema; contributes to regional haze and impair visibility. }\end{array}$ \\
\hline & EC & Primary particles; $2 \%$ - $20 \%$ of PM mass. & Scatters and absorbs solar radiation, thus affecting climate. \\
\hline & OC & $\begin{array}{l}\text { Primary or secondary particles; } 60 \%-70 \% \\
\text { of PM mass. }\end{array}$ & Some are carcinogens or irritants. \\
\hline & $\begin{array}{l}\text { Trace } \\
\text { elements }\end{array}$ & Concentrate in the fine particles. & Some metal elements are toxic. \\
\hline \multirow{3}{*}{ VOCs } & Acrolein & Can be adsorbed on particles. & An organic irritant and a potent lachrymatory agent. \\
\hline & Formaldehyde & Can be adsorbed on particles. & $\begin{array}{c}\text { An organic irritant and a carcinogen linked to nasal and } \\
\text { throat cancer and leukemia. }\end{array}$ \\
\hline & Isocyanic acid & $\begin{array}{l}\text { Found in both cigarette smoke and } \\
\text { vegetation fire smoke. }\end{array}$ & Contribute to cardiovascular problems and inflammation. \\
\hline SVOCs & PAHs & $\begin{array}{l}\text { Specific species varies with composition of } \\
\text { vegetation; condense or adsorbed onto fine } \\
\text { particles or as volatiles in the vapor phase. }\end{array}$ & Carcinogenic and mutagenic. \\
\hline \multirow{5}{*}{$\begin{array}{l}\text { Permanent } \\
\text { gases }\end{array}$} & $\mathrm{CO}_{2}$ & Dependent on availability of $\mathrm{O}_{2}$. & Greenhouse gas \\
\hline & $\mathrm{CO}$ & $\begin{array}{l}\text { Dependent on availability of } \mathrm{O}_{2} \text {; abundant } \\
\text { only in immediate vicinity of fire. }\end{array}$ & $\begin{array}{l}\text { Toxicity due to reducing oxygen-carrying capacity of the blood, } \\
\text { known as hypoxia. }\end{array}$ \\
\hline & $\mathrm{CH}_{4}$ & $\begin{array}{l}\text { Global warming potential } 21 \text { times higher } \\
\text { than } \mathrm{CO}_{2} .\end{array}$ & Greenhouse gas \\
\hline & $\mathrm{NO}_{\mathrm{x}}$ & $\begin{array}{l}\text { Reactive; concentrations change with } \\
\text { distance from fire. }\end{array}$ & Irritant and precursors of $\mathrm{O}_{3}$. \\
\hline & Water vapor & Can condense onto fine particles. & Contributes to regional haze and impairs visibility. \\
\hline $\begin{array}{l}\text { Secondary } \\
\text { products }\end{array}$ & $\mathrm{O}_{3}$ & $\begin{array}{l}\text { Secondary product of } \mathrm{NO}_{\mathrm{x}} \text {, VOCs and CO; } \\
\text { can be transported over long distances. }\end{array}$ & Causes chest pain and respiratory problems. \\
\hline
\end{tabular}

$\mathrm{PM}=$ particulate matter; $\mathrm{PM}_{2.5}=$ particulate matter that less than $2.5 \mu \mathrm{m}$ in equivalent aerodynamic diameter; $\mathrm{EC}=$ elemental carbon; $\mathrm{OC}=$ organic carbon; $\mathrm{VOCs}=$ volatile organic compounds; $\mathrm{SVOCs}=$ semi-volatile organic compounds; $\mathrm{PAHs}=$ polycyclic aromatic hydro-carbons; $\mathrm{CO}_{2}=$ carbon dioxide; $\mathrm{CO}=$ carbon monoxide; $\mathrm{CH}_{4}=$ methane; $\mathrm{NO}_{\mathrm{x}}=$ nitrogen oxides; $\mathrm{O}_{3}=$ ozone. 
materials. OC can be primary particles or secondary particles that are formed through gas-to-particle conversion processes such as nucleation, condensation, and agglomeration [8]. The hot vapors of low-volatility organic products can either nucleate or condense on the surface of pre-existing particles as the smoke plume cools down, yielding fine particles [25]. Many of these organic compounds are irritants, and some are carcinogens. Trace metal elements are known to concentrate in fine particles.

Size distributions of smoke PM are sensitive to specific combustion conditions but generally can be well represented by a bimodal log-normal distribution with a fine particle mode with mass median aerodynamic diameter (MMAD) around $0.1-0.3 \mu \mathrm{m}$ and a coarse particle mode with MMAD around 5 - $10 \mu \mathrm{m}$ [23] [26] [27]. Fine particles are produced from combustion, and larger particles are entrained into the smoke column as a result of the turbulence and buoyancy generated by the fire [26]. About $90 \%$ of PM in biomass smoke is $\mathrm{PM}_{10}$, (10 $\mu \mathrm{m}$ or smaller in equivalent aerodynamic diameter) [28] [29] [30]. About 70\% - 90\% of PM in smoke is $\mathrm{PM}_{2.5},(2.5 \mu \mathrm{m}$ or smaller in equivalent aerodynamic diameter) [4]. Particles of this size range are not easily removed by gravitational settling and therefore can be transported over long distances [23] [31]. The size of particles in the air affects their potential to cause health problems. The depth of particle penetration into the lungs and the likelihood of their exhalation depend on their size [32]. Coarse particles affect the nasopharyngeal region, whereas fine particles can penetrate the large airways of the trachea, bronchi, and bronchioles and even reach the alveoli [20] [33].

Inhaled fine particles can cause an inflammatory response in the respiratory system even though the material itself is inherently nontoxic [34] [35]. Ultrafine EC particles have a core structure of graphitic spheres around $20-40 \mathrm{~nm}$, which offers large surface area for radical production and has great potential to cause inflammation [36]. In vitro toxicology studies have shown that carbonaceous fine particles in fire smoke are capable of initiating the production of free radicals [37]. Ultrafine particles also show a great degree of active inhibition of phagocytosis (by which particles are removed from the lungs) [38]. On the other hand, coarse particles were found to be relatively rich in endotoxin, a family of lipopolysaccharides known for its inflammatory ability. Therefore, both coarse and fine fractions induced inflammation in vitro, but for different reasons [36] [39]. In a study of wildfires in California, Nakayama et al. [40] found PM from air in an urban area and that near a wildfire induced very different inflammatory, oxidative stress, and xenobiotic responses in human bronchial epithelial cells. Smoke PM acts as a vehicle to carry absorbed hazardous compounds into the respiratory tract [8]. The absorbed hazardous compounds may include VOCs such as formaldehyde and acrolein [32], SVOCs such as PAHs and dioxin [7] [20], gases such as nitrogen dioxide $\left(\mathrm{NO}_{2}\right)$ [18], and heavy and toxic metal elements such as $\mathrm{Pb}$ and $\mathrm{Hg}$ [41]. The inhalation of $\mathrm{PM}$ may cause coughing, asthma, upper and lower respiratory tract infections, COPD (chronic obstructive pulmonary disease), and ischemic cardiomyopathy [4] [42] [43].

\subsection{VOC}

Combustion of organic material can result in the formation of organic irritant products 
such as a range of VOC gases called aldehydes [7]. Of this group, formaldehyde and acrolein are most commonly considered, although they may not be the sole organic irritants, and other compounds such as acetaldehyde and butyraldehyde also may be present in fire smoke [44] [45]. Combustion of cellulose-based material such as wood has been demonstrated to evolve significant quantities of formaldehyde and acrolein [7].

Aldehydes can irritate eyes and the respiratory system and may trigger asthma [27]. They can also cause contact dermatitis and urticaria [43]. Formaldehyde is a potent sensory irritant; it causes mild to moderate irritation of the upper respiratory tract and eyes at concentrations of $0.2-3 \mathrm{ppm}$ [46] and may decrease sensory capacity [4]. Formaldehyde was long considered a probable human carcinogen based on experimental animal studies and limited evidence of human carcinogenicity [47]. Long-term inhalation of formaldehyde may cause nasal and nasopharyngeal cancer [48]. In June 2004, the International Agency for Research on Cancer (IARC) reclassified formaldehyde from a probable human carcinogen to a known human carcinogen based on sufficient epidemiological evidence that formaldehyde causes nasopharyngeal cancer in humans [49]. Acrolein, which is known to affect respiratory functions at concentrations as low as $100 \mathrm{ppb}$ [27], is the most potent of the irritants, causing the onset of lachrimation and eye irritation at concentrations of $0.5-5 \mathrm{ppm}$ within a 10-min exposure period [50], and it causes cellular toxicity in the upper respiratory tract and ciliary stasis [43]. Acrolein inhibits the ability of scavenger cells in the lungs to kill bacteria, thus increasing the possibility of respiratory infection [51].

Isocyanic acid is a potentially toxic compound found in both cigarette smoke and vegetation fire smoke, and it was recently identified in outdoor air under the influence of wild fires [52]. The limited information available indicates the acid could contribute to cardiovascular problems and inflammation, although effects at the concentrations present in wild fire smoke have yet to be observed [3].

\subsection{SVOCs}

Incomplete combustion of organic material in a low- $\mathrm{O}_{2}$ environment can produce more complex molecules in the form of SVOCs such as PAHs, which are mixtures of a large group of organic compounds containing a minimum of two fused benzene rings [7] [27]. Some of the most commonly known PAHs include benzo(a)pyrene (BaP), naphthalene, and anthracene [53]. The distribution of combustion PAHs in fire smoke is associated with aerosols, either on particles or as volatiles in the vapor phase, and they can be disseminated from their sources over regional areas and potentially transported over global distances [1]. Elevated levels of PAHs in large areas were observed during the 1997 fires in Indonesia [54]. Emissions of PAHs were measured in a wind tunnel for simulated open burning of cereal grasses and tree prunings [55] [56]. Lighty et al. [5] found that PAHs emissions were more strongly influenced by burning conditions than by the type of fuel, because weakly spreading fires were observed to produce higher levels of the heavier PAHs, with more of the PAHs partitioned to the particulate phase. 
For low-intensity backing fires, the ratio of $\mathrm{BaP}$ to $\mathrm{PM}$ is higher by almost 2 orders of magnitude over that for heading fires [57].

Many of the PAHs compounds are known to be potentially carcinogenic and mutagenic based on animal experiments or data from occupational exposure to PAHs mixtures [7]. The anthropogenic PAHs sources, mainly from combustion processes, are by far the major contributors of hydrocarbons with known health hazards to the environment [1]. Clinical trials have demonstrated the carcinogenic effects of over 30 PAHs and hundreds of PAHs derivatives [58]. High-dose exposures of some PAHs increase the risk of bladder cancer and lung cancer [59]. Most of the experimental data relating to carcinogenicity of PAHs is from chronic exposure studies in animals. Risks from a single acute exposure remain uncertain and are likely to be small [7].

\subsection{Permanent Gases}

The dominant fraction of vegetation fire emissions is released as carbon with $\mathrm{CO}_{2}$ and CO representing about $90 \%-95 \%$ of the total emitted carbon [6]. Less than $5 \%$ of the carbon is emitted as $\mathrm{PM}$ [22], and most of the remaining carbon is composed $\mathrm{of} \mathrm{CH}_{4}$, VOCs, and SVOCs [11] [60]. Both $\mathrm{CO}_{2}$ and $\mathrm{CH}_{4}$ are important greenhouse gases (GHGs). Inhalation of $\mathrm{CO}_{2}$ at concentrations in most fire smoke is not considered to cause significant toxicity on its own but will give rise to physiological effects that enhance the toxicity of other combustion products [7]. An increase in $\mathrm{CO}_{2}$ concentration will stimulate the rate and depth of respiration, and a $50 \%$ increase in respiratory minute volume was observed at concentration of $2 \% \mathrm{CO}_{2}$ [61]. The production of $\mathrm{CO}$ in a fire is dependent on availability of $\mathrm{O}_{2}$, and it is often second in abundance to $\mathrm{CO}_{2}$ and water vapor in vegetation fire smoke. The toxicity of $\mathrm{CO}$ is a concern due to the fact that the affinity of hemoglobin for CO is $200-250$ times greater than the affinity for $\mathrm{O}_{2}$ [62]. In response to the exposure to $\mathrm{CO}$, production of carboxyhemoglobin $(\mathrm{COHb})$ is increased in the blood of humans, which reduces the capacity of red blood cells to transport $\mathrm{O}_{2}$ [27]. In excessive amounts, $\mathrm{COHb}$ causes $\mathrm{O}_{2}$ deprivation, damages body tissues, induces coughing and cold-like symptoms, and complicates atherosclerosis and coronary heart disease [24] [63]. Symptoms of CO exposure at concentrations below lethal level may include neurological effects such as headache, weakness, dizziness, confusion, visual impairment, and coma [62].

Nitrogen oxides $\left(\mathrm{NO}_{\mathrm{x}}\right)$ such as nitric oxide $(\mathrm{NO})$ and $\mathrm{NO}_{2}$ are commonly present as mixtures in fire smoke. Because of the fairly low combustion temperatures in vegetation fires, atmospheric $\mathrm{N}_{2}$ is not converted to fixed nitrogen to a significant extent, and the nitrogen species emissions are based only on fuel nitrogen [6]. Linear relationships have been found between fuel nitrogen content and $\mathrm{NO}_{\mathrm{x}}$ emissions in savanna fires [64]. The most abundant $\mathrm{N}$ species in smoke is $\mathrm{NO}$, and $\mathrm{NO}_{2}$ represents around $10 \%$ of $\mathrm{NO}_{\mathrm{x}}$ in smoke near the fire [12] [65]. In smoke away from the fire, more $\mathrm{NO}_{2}$ is likely to be present because $\mathrm{NO}$ will be converted to $\mathrm{NO}_{2}$ when sufficient $\mathrm{O}_{2}$ is present [6]. $\mathrm{NO}_{2}$ has been shown to cause significant increases in airway resistance in healthy individuals at exposures as low as $2.5 \mathrm{ppm}$, and individuals with asthma are more sensitive, with a 
threshold around $0.2 \mathrm{ppm}$ [7]. $\mathrm{NO}_{\mathrm{x}}$ are less soluble than other irritant gases and are therefore more likely to reach the bronchioles and alveoli following inhalation, giving rise to pulmonary damage [7].

\subsection{Water Vapor}

The water vapor from fire can condense onto fine particulate matter and increase haze formation. High moisture content in vegetation fuels reduces combustion efficiency and produces more smoke.

\subsection{Secondary Products of the Smoke Plume}

Secondary products can be produced in the smoke plume through photochemical reactions under solar radiation. VOCs, $\mathrm{NO}_{\mathrm{x}}$, and $\mathrm{CO}$ have been identified as precursors to ground level ozone $\left(\mathrm{O}_{3}\right)$ [66]. The production of $\mathrm{O}_{3}$ occurs either in the original plume or as a result of the smoke plume interacting with existing pollutants in the atmosphere [18]. Elevated $\mathrm{O}_{3}$ concentrations by up to $50 \mathrm{ppb}$ for a short period of time were observed at the edge of fire smoke plumes and in smoke plumes traveling long distances and affecting large areas [67] [68] [69] [70]. The ambient $\mathrm{O}_{3}$ concentrations were increased by about $20 \mathrm{ppb}$ above background levels throughout a 2 million $\mathrm{km}^{2}$ region during the seasons of large-scale tropical vegetation fires [71]. Exposure to $\mathrm{O}_{3}$ can cause chest pain, headaches, respiratory problems such as pulmonary edema, and aggravation of pre-existing asthma and pre-existing arrhythmia [4].

\subsection{Other}

Free radicals are abundantly produced in combustion. Some free radicals persist up to 20 min following formation and may be of concern to people exposed to them because free radicals may react with human tissues [27]. Radioactive species can occasionally be found in vegetative fire smoke. Their origin can be radioactively contaminated vegetation fuel [8]. Herbicides and insecticides sprayed on vegetation may also become re-suspended in the air, although research suggests that concentrations would be well below levels that pose known health risks [72]. Dioxins are extremely persistent and widely distributed in the environment. They are found in soils in remote areas and are sometimes present in vegetation fire smoke [20] [72] [73]. Dioxins increase susceptibility to infections (for example, Staphylococcus aureus) by inhibiting humoral immunity and by affecting T-lymphocytes and $\mathrm{B}$ lymphocytes [74]. $\mathrm{SO}_{\mathrm{x}}$ are usually produced in small quantities because sulfur content in vegetation fuel is generally low [18] [75]; however, high amounts of sulfur-based compounds can be produced when sulfur-rich vegetation or soil are burned, such as the Yellowstone National Park fires [76].

\section{Concentrations, Emission Ratios, and Emission Factors}

Determining concentrations of smoke components is difficult due to the dynamic situation and rapid changes in concentration profiles in space and time. Particulate matter in smoke is a dynamic entity in terms of its concentration, size distribution, and chem- 
ical content due to coagulation, diffusion, deposition and sedimentation of particles, and condensation, adsorption and desorption of gases on the particles [32]. Some hazardous compounds in smoke such as $\mathrm{CO}$ are present only in significant quantities in the immediate vicinity of the fire [7], whereas $\mathrm{O}_{3}$ is present only downwind of firetransport over distances [8]. $\mathrm{NO}_{2}$ concentrations change with distance from fire [6]. Organic irritants (acrolein, formaldehyde, etc.), complex molecules (PAHs, dioxins, etc.), and $\mathrm{PM}_{2.5}$ can be transported long distances and be present in the smoke plume far away from the source [1] [7] [8].

The two parameters often used to characterize emissions from fires are emission factor and emission ratio. Emission factor is defined as the amount of a smoke component generated per unit mass of fuel burned. Emission factor of PM, sometimes also referred to as smoke yield, ranges from fractions of a percent to about $20 \%$ of the fuel mass [32]. Smoke ratio relates the emission of a smoke component of interest to that of a reference component, such as $\mathrm{CO}_{2}$ or $\mathrm{CO}$ [6]. Fully oxidized compounds correlate best with $\mathrm{CO}_{2}$, whereas partially oxidized compounds and hydrocarbons tended to correlate linearly with $\mathrm{CO}$ [77]. Emission ratios are usually expressed in terms of molar ratios for gases, or in units of g per $\mathrm{kg} \mathrm{CO}_{2}$-carbon for PM. Le Canut et al. [78] and Delmas et al. [79] discussed various techniques for calculation of emission ratios and emission factors. A carbon balance method is often used to determine carbon mass in a smoke component as a fraction of the carbon mass in the total combustion products $\left(\mathrm{CO}_{2}, \mathrm{CO}, \mathrm{PM}\right.$ carbon, $\mathrm{CH}_{4}$, and VOCs). When deriving emission factors from emission ratios, a fuel carbon content of $45 \%$ is usually assumed if the data are not available [6] [32].

Concentrations, emission ratios, and emission factors of smoke components from vegetation fires in the literature are summarized in Table 2. Results from different studies are highly variable largely due to variability in fuel and combustion conditions. The $\mathrm{PM}_{10}$ and $\mathrm{PM}_{2.5}$ concentrations at downwind communities under influence of vegetation fire smoke can be significantly higher than the corresponding air quality standards. Concentrations of acrolein were below the National Institute for Occupational Safety and Health (NIOSH) 8-hr exposure limits, whereas concentrations of formaldehyde were higher than the NIOSH 8-hr exposure limits both at fires and in downwind communities. The contribution of vegetation fire smoke on downwind $\mathrm{O}_{3}$ concentrations is a big concern, because it can be as high as $67 \%$ of the current 8-hr $\mathrm{O}_{3}$ standard.

Inventory estimates of emissions of smoke components from open fires are traditionally calculated from empirical emission factors, ecosystem-based estimates of fuel loading per area, burned area, and combustion completeness using the equation: $\mathrm{E}=\mathrm{A} \times$ $\mathrm{FL} \times \mathrm{CC} \times \mathrm{EF}$ [5] [60], in which $\mathrm{E}$ is fire emissions; A is burned area; FL is fuel load, which depends on vegetation type, climate, soil type, time since last fire, and other competing processes; CC is combustion completeness, which describes the fraction of the fuel that is combusted during a fire event, depending on the type of fire, the type of fuel, and its moisture content [60]; EF is emission factor. Detecting burned area over large scales is not easy. Recent burn area products are often based on high-quality satellite data [106] [107]. 
Table 2. Concentrations, emission ratios, and emission factors of smoke components from vegetation fires in the literature.

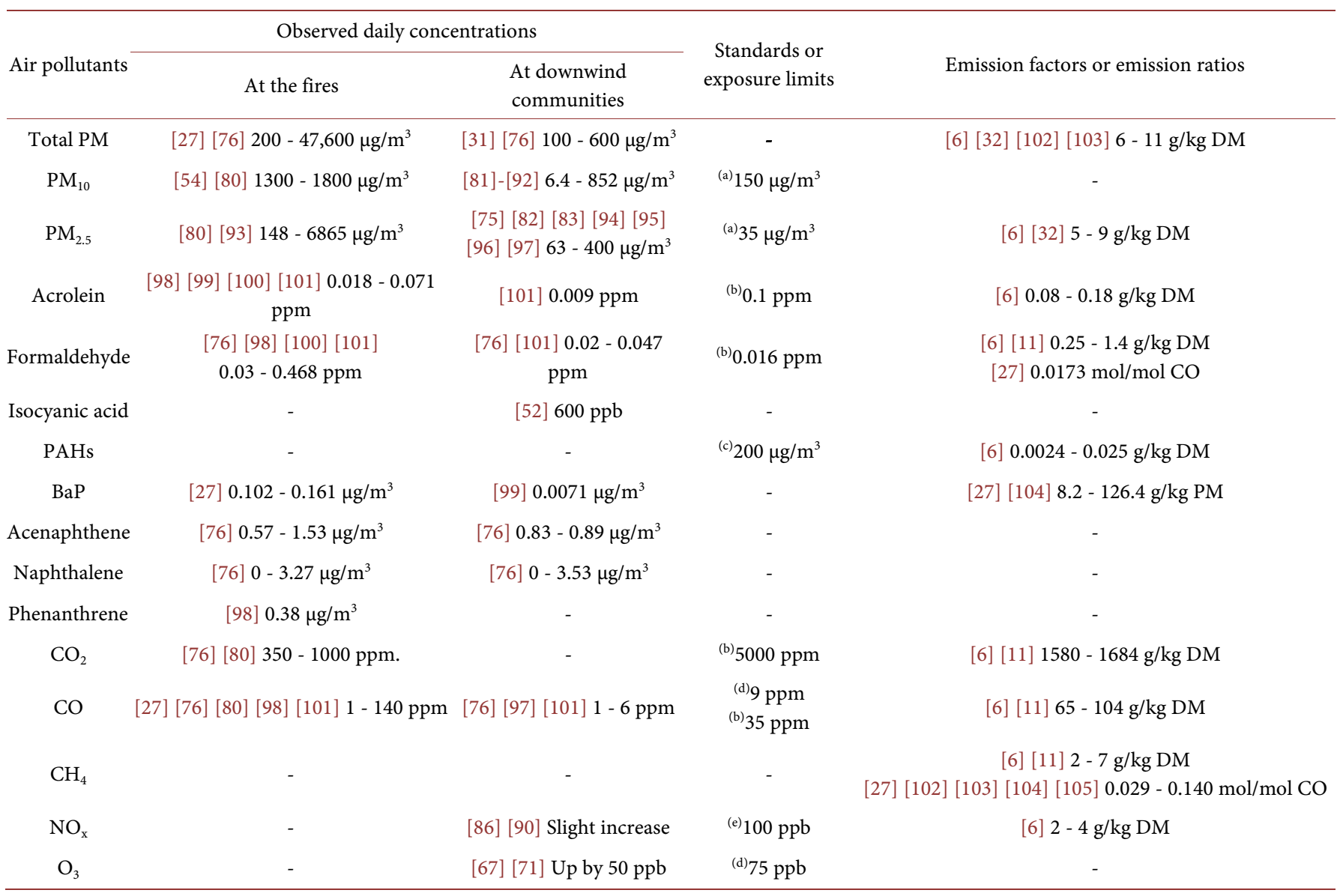

$\mathrm{PM}=$ particulate matter; $\mathrm{PM}_{10}=$ particulate matter that less than $10 \mu \mathrm{m}$ in equivalent aerodynamic diameter; $\mathrm{PM}_{2.5}=$ particulate matter that less than $2.5 \mu \mathrm{m}$ in equivalent aerodynamic diameter; $\mathrm{PAHs}=$ polycyclic aromatic hydrocarbons; $\mathrm{BaP}=$ benzo(a)pyrene; $\mathrm{CO}_{2}=$ carbon dioxide; $\mathrm{CO}=$ carbon monoxide; $\mathrm{CH}_{4}=$ methane; $\mathrm{NO}_{\mathrm{x}}=$ nitrogen oxides; $\mathrm{O}_{3}=$ ozone; $\mathrm{DM}=$ dry matter. (a) National Ambient Air Quality Standards (NAAQS) 24-hr standards; (b) National Institute for Occupational Safety and Health (NIOSH) 8-hr exposure limits; (c) Occupational Safety and Health Administration (OSHA) 8-hr exposure limits; (d) NAAQS 8-hr standards; (e) NAAQS 1-hr standards.

\section{Health Impacts of Vegetation Fire Smoke Exposure}

In fire smoke exposure, people are exposed to a complex mixture rather than many isolated components, so the health effect of smoke exposure is the combined effects of all hazardous smoke components. Different components of smoke can interact and produce additive or synergistic effects, resulting in higher toxicity [8]. Smoke health effects are determined by the length of time exposed, volume of air breathed, concentration of pollutants in the air, and individual health conditions. The most common pathway of smoke exposure is inhalation, followed by dermal absorption and ingestion [4]. The general health risks from acute fire smoke exposure have been widely recognized by organizations such as the US Environmental Protection Agency [108], the US Centers for Disease Control and Prevention [109], and the Pediatric Environmental Health Specialty Units [110]. The health impacts of fire smoke exposure have been documented in many studies, particularly among children and the elderly, although concentrations and constituents of smoke may vary by specific sources. Many components of 
vegetation fire smoke are irritants. Symptoms from acute exposure to smoke include teary and burning eyes, runny nose, and scratchy and sore throat [4]. Air pollution in general interferes with heart and lung processes. The health effects considered to be linked with vegetation fire smoke include chronic obstructive pulmonary disease (COPD), reduced lung function, asthma, heart disease, bronchitis, rhinitis, and various respiratory problems (Table 3). Many studies have investigated smoke cardiopulmonary linkages by conducting surveys of utilization of medical facilities in communities near fire events. Smoke exposure may depress respiratory immune defenses and has been linked with emergency department visits for upper and lower respiratory effects. In a study of Darwin, Australia, researchers found that when $\mathrm{PM}_{10}$ concentrations from fires exceeded $40 \mu \mathrm{g} / \mathrm{m}^{3}$, emergency department admissions for asthma increased sharply [111], although that concentration is far below the current 24-hr standards of $150 \mu \mathrm{g} / \mathrm{m}^{3}$ established in the National Ambient Air Quality Standards (NAAQS). Although epidemiologic evidence suggested mainly respiratory effects, recent research indicated cardiovascular health risks also can be a concern, although sometimes only for people of a sensitive group [92] [96] [112] [113] [114]. Larson and Koenig [42] found that smoke inhalation reduces red blood cell levels and damages cellular membranes, as indicated by increases in albumin and lactose dehydrogenase and depression of macrophage activity. Tan et al. [115] found acute exposure to PM in smoke is associated with hematologic changes in humans. Generalizations must be made with caution, however, because the constituents of smoke may vary for different fires; the impact of fire smoke on cardiovascular health requires further investigation.

Wildland firefighters comprise an occupational group with high exposure to vegetation fire smoke. Studies of wildland firefighters clearly indicate an association between exposure and acute effects on respiratory health. Longer-term effects, lasting for a 3 6-month firefighting season, also have been observed in most studies although these

Table 3. Summary of observed symptoms or health impacts of vegetation fire smoke exposure in literature.

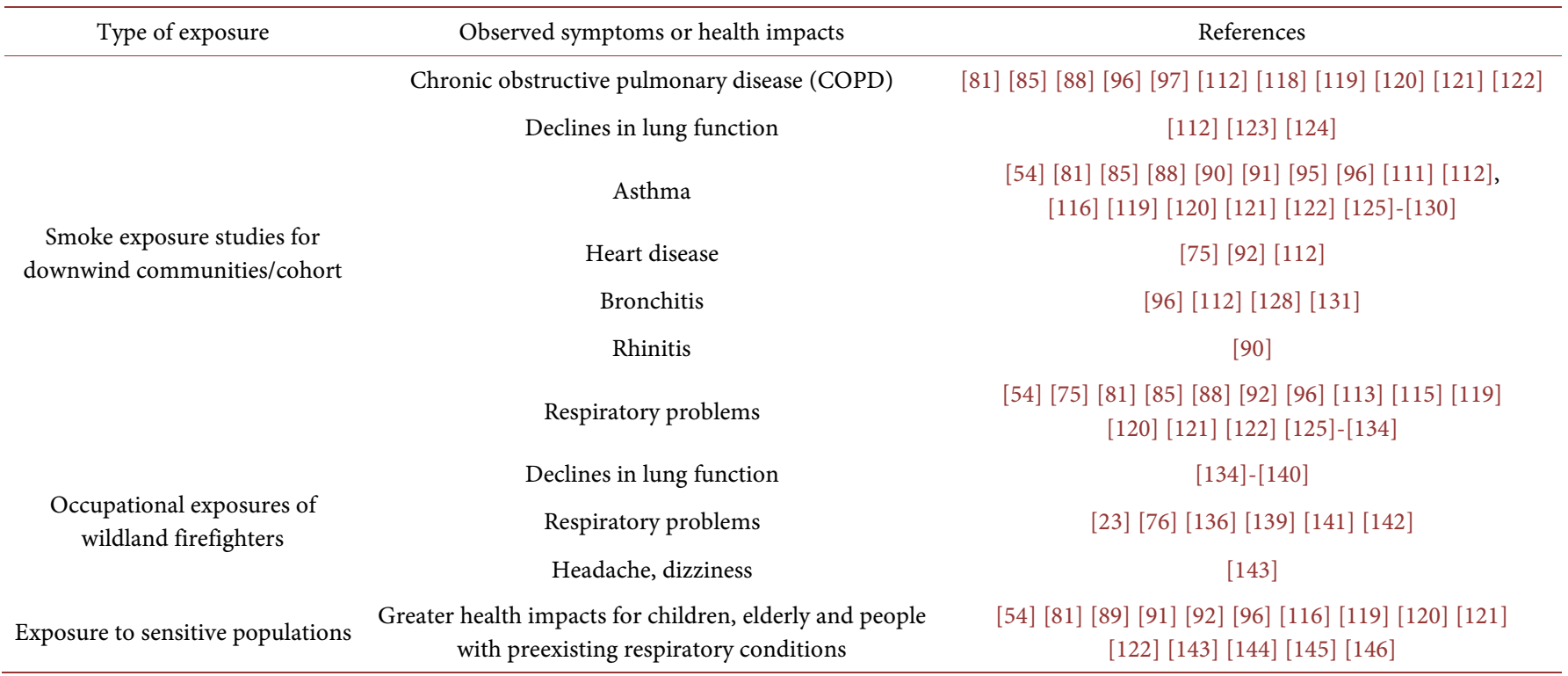


effects appear to be relatively small and may be reversible [23]. Individuals react differently to air pollutants. Many studies have shown children, elderly people, pregnant women, smokers, and people with pre-existing respiratory problems were especially vulnerable to health effects from fire smoke [91] [92] [96] [110] [116]. Delfino et al. [96] found the strongest associations between $\mathrm{PM}_{2.5}$ in smoke and hospital admissions were for people over 65 years old ( $10 \%$ increase per $10 \mu \mathrm{g} / \mathrm{m}^{3} \mathrm{PM}_{2.5}$ ) and under 5 years old $\left(8 \%\right.$ per $\left.10 \mu \mathrm{g} / \mathrm{m}^{3} \mathrm{PM}_{2.5}\right)$. Children are more likely to be affected because their airways are still developing, and they breathe more air per pound of body weight than adults. Elderly people are more likely to be affected, possibly because they are more likely to have pre-existing heart or lung conditions than younger people. People who have pre-existing conditions respond to lower dosages and shorter durations of exposure to PM than healthy people. Osterman and Brauer [117] reported that new cases of pulmonary diseases emerge when PM occurs in the range of $10-100 \mathrm{mg} / \mathrm{m}^{3}$, whereas pre-existing cases were aggravated by the occurrence of PM in the range of $20-40$ $\mathrm{mg} / \mathrm{m}^{3}$ for $\mathrm{PM}_{2.5}$ and $40-50 \mathrm{mg} / \mathrm{m}^{3}$ for $\mathrm{PM}_{10}$.

\section{Environmental Impacts of Fire Smoke}

Vegetation fire smoke is an important source of many reactive organic substances in the atmosphere. When a smoke plume passes over an urban or industrial areas, it can interact with urban or industrial pollutants and produce secondary products such as $\mathrm{O}_{3}$ [66], which may cause additive or even synergistic results [18] [20] [80]. The water vapor from fire can condense onto fine particles and increase haze formation. The fine soot particulate matter in smoke has a size range near the wavelength of visible light $(0.4-0.7 \mu \mathrm{m})$ and therefore can efficiently scatter light and reduce visibility [8]. Aerosol particles emitted from vegetation fires can also act as cloud condensation nuclei and therefore have potential impacts on cloud properties and precipitation [147] [148]. Most fires deposit their emissions into the atmospheric boundary layer; i.e., below about $5 \mathrm{~km}$ [149] [150]. Under favorable meteorological (high atmospheric instability) and fire conditions (high energy release), fire emissions can be injected into the upper troposphere or even the lower stratosphere [151] [152]; consequently, the lifetime of air pollutants in smoke can be substantially enhanced, and hence can affect greater regions or have longer impacts [60].

Smoke aerosols absorb incident radiation and may perturb radiation budgets locally, regionally, and globally due to their light-scattering and absorption effects [1] [153]. Vegetation fire emissions also contribute to the global burden of GHGs [60]. Vegetation fires, both prescribed and wildfires, are becoming a global concern [1]. In addition to their impacts on air quality and climate, fires can affect soil and water quality through deposition of smoke. In a study following fires in 2005 and 2006 in three watersheds in Southern California, researchers found that organic or particulate-bound mercury in surface soils can be more readily deposited in waterways after a fire [154].

\section{Risk Assessment of Fire Smoke}

Large quantities of toxic air pollutants may be emitted during the period of intensive 
vegetation fires (e.g., seasonal prescribed burning), but little is known about levels of exposures in affected communities and the potential health impacts of such exposures. Although many agencies keep track of fire smoke emissions through an annual reporting system, few have the ability to track burning activity on a daily basis, and finding consistent data on source characteristics is difficult [155]. Although large quantities of data are available on urban exposures to air pollutants, measurements of air pollutants in rural areas where fires occur is often lacking. Remote-sensing data recently became available for active fire and burned-area detection [156], and fire emission inventories are often based on a combined approach using burned area and active fire counts from satellites accompanied by biogeochemical modeling of the available fuel load [60] [157] [158]. Products are being developed that use satellite-derived vegetation and other attributes to estimate the mass, structure, and distribution of fuel. Improved application of satellite imagery plus ground-level air monitoring could help forecast smoke movements. Smoke modeling tools are being developed to take into account weather conditions along with the smoke emission data to evaluate the impacts of smoke and the resulting concentrations of air pollutants.

Monitoring smoke levels from open vegetation fires is often a difficult task because these fires usually occur in remote areas, and uncertainties in smoke concentrations are numerous because they are dynamic and can vary widely within short distances. Because smoke is highly visible, it is possible to estimate smoke levels using a visibility index [159] [160]. Visibility can be determined by facing away from the sun and looking for landmarks at known distances. The visibility range is the distance at which even high-contrast objects cannot be seen (e.g., a dark building viewed against the sky at noon) [160]. When visibility has been determined, Figure 2 can be used to estimate equivalent $\mathrm{PM}_{2.5}$ levels and the associated air quality category. The visibility index is not effective at night or when humidity is high.

For detailed risk assessment, chemical analysis of smoke PM samples should be conducted to identify the proportion of various functional groups (PAHs, EC, trace metals, etc.). Marker compounds, which provide a source-specific chemical fingerprint, may be identified and used to distinguish contributions of vegetation fire from other sources [23].

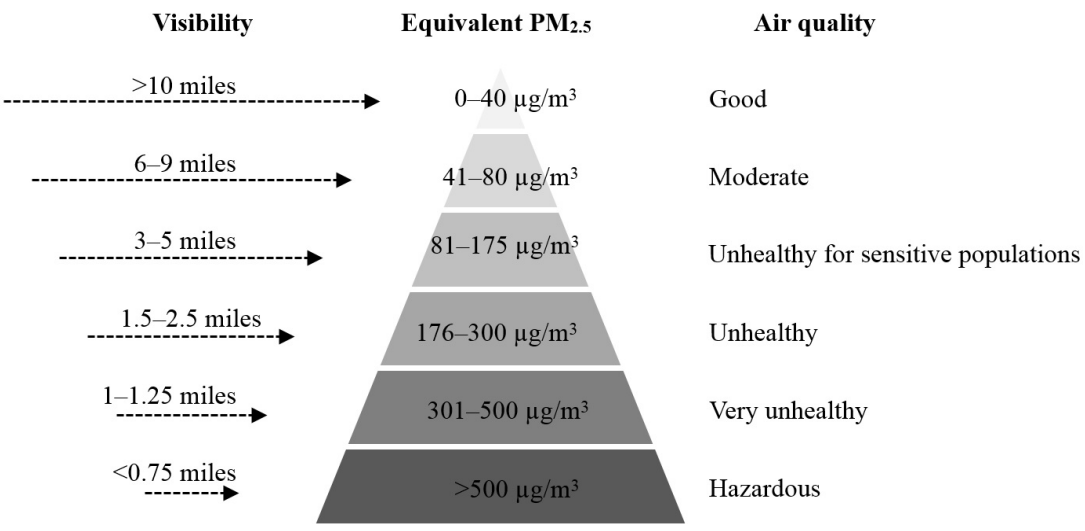

Figure 2. Assessing $\mathrm{PM}_{2.5}$ levels and air quality based on visibility index (data from [161]). 


\section{Conclusions}

Despite many limitations, understanding of vegetation fire smoke is increasing along with the growing interest in this subject among the general public, policymakers, and land managers. Vegetation fire smoke is a complex mixture of airborne solid and liquid particulates, vapors and gases, which can contain thousands of individual compounds involving a wide range of chemicals, in categories such as PM, VOCs, SVOCs, inorganic gases, and water vapor. Smoke aerosols are dynamic with respect to size distribution of PM and adsorption of hazardous compounds. Reported concentrations of smoke components from vegetation fires from different studies were highly variable because of the variability in fuel and combustion conditions. Generally, the $\mathrm{PM}_{10}$ and $\mathrm{PM}_{2.5}$ concentrations at downwind communities affected by vegetation fire smoke can be significantly higher than the corresponding air quality standards. The contribution of vegetation fire smoke on downwind $\mathrm{O}_{3}$ concentrations is also a big concern. Most research on smoke effects investigates single components of smoke such as PM, PAHs, and aldehydes. More attention needs to be given to the potential for interactive effects among smoke components as well as between smoke components and preexisting pollutants in air; e.g., the formation of secondary aerosols. Considering vegetation fire smoke and urban or industrial pollutants usually differ markedly in compositions; they can have significantly different toxicological effects. It has been pointed out that serious damage to public health could occur even when air pollution levels are below the current air quality standards, which are based on results mainly from epidemiology studies on urban pollution. The health impacts of fire smoke exposure have been documented in many studies, although sometimes only for people of a sensitive group. In areas where annual or seasonal burning is practiced, effects of chronic exposure to vegetation fire smoke could pose considerable health risks; however, very few studies have explored long-term health effects. For the range of identified effects, much is unknown about whether the effects are reversible or permanent. More research is needed to confirm the adequacy of the current standards for the protection of sensitive populations exposed to vegetation fire smoke. Effectiveness of health protection measures such as use of dust masks or advising the population to remain indoors needs to be evaluated, and exposure limits of sensitive populations may need to be considered so individual and community-based intervention strategies can be developed in the most cost-effective way.

Accurate data on emissions from vegetation fires are required to determine major factors that influence the emissions, to represent the emissions quantitatively in atmospheric chemistry and transport models, and to evaluate impacts. Specialized field monitoring methods and air quality models need to be developed to overcome inherent difficulties. Further exploration and refinement of metrics based on remote-sensing data are desirable, especially in areas where air quality monitoring is practically nonexistent. The ability to trace smoke PM to its sources is necessary to identify the smoke components that characterize smoke from various types of vegetation fires and distinguish fire smoke from "background" urban air pollution. Identifying new marker compounds is important for transport and fate studies of smoke emissions. As smoke com- 
ponents are prioritized in terms of their health impacts, additional hazardous smoke components may be identified. Some of the research gaps in existing knowledge are summarized as follows.

- Toxicological differences between vegetation fire smoke and urban or industrial pollutants.

- Marker compounds and additional hazardous smoke components.

- Smoke dynamics and potential interactive effects of smoke components.

- Exposure limits for sensitive populations.

- Long-term health effects of exposure.

- Specialized field monitoring methods and air quality models.

- Effectiveness of health protection measures.

- Smoke contribution to regional or global climate.

\section{Acknowledgements}

This is contribution 14-153-J from the Kansas Agricultural Experiment Station.

\section{Funding}

Publication of this article was funded in part by the Kansas State University Open Access Publishing Fund.

\section{References}

[1] Simoneit, B.R.T. (2002) Biomass Burning-A Review of Organic Tracers for Smoke from Incomplete Combustion. Applied Geochemistry, 17, 129-162.

https://doi.org/10.1016/S0883-2927(01)00061-0

[2] Wegesser T.C., Pinkerton, K.E. and Last, J.A. (2009) California Wildfires of 2008: Coarse and Fine Particulate Matter Toxicity. Environmental Health Perspectives, 117, 893-897. https://doi.org/10.1289/ehp.0800166

[3] Weinhold, B. (2011) Fields and Forests in Flames: Vegetation Smoke and Human Health. Environmental Health Perspectives, 119, A386-A393. https://doi.org/10.1289/ehp.119-a386

[4] Fowler, C.T. (2003) Human Health Impacts of Forest Fires in the Southern United States: A Literature Review. Journal of Ecological Antropology, 7, 39-59. https://doi.org/10.5038/2162-4593.7.1.3

[5] Lighty, J.S., Veranth, J.M. and Sarofim, A.F. (2000) Combustion Aerosols: Factors Governing Their Size and Composition and Implications to Human Health. Journal of the Air \& Waste Management Association, 50, 1565-1618. https://doi.org/10.1080/10473289.2000.10464197

[6] Andreae, M.O. and Merlet, P. (2001) Emission of Trace Gases and Aerosols from Biomass Burning. Global Biogeochemical Cycles, 15, 955-966. https://doi.org/10.1029/2000GB001382

[7] Wakefield, J.C. (2010) A Toxicological Review of the Products of Combustion. Health Protection Agency, Centre for Radiation, Chemical and Environmental Hazards, Chemical Hazards and Poisons Division.

[8] Statheropoulos, M. and Goldammer, J.G. (2007) Vegetation Fire Smoke: Nature, Impact and Policies to Reduce Negative Consequences on Humans and the Environment. Pro- 
ceedings of 4th International Wildfire Conference, Sevilla, 14-17 May 2007.

[9] Hardy, C.C., Ottmar, R.D., Peterson, J.L. and Core, J.E. (2001) Smoke Management Guide for Prescribed and Wildland Fire: 2001 Edition.

[10] Tewarson, A., Jiang, F.H. and Morikawa, T. (1993) Ventilation-Controlled Combustion of Polymers. Combustion and Flame, 95, 151-169. https://doi.org/10.1016/0010-2180(93)90058-B

[11] Urbanski, S.P., Hao, W.M. and Baker, S. (2009) Chemical Composition of Wildland Fire Emissions. In: Bytnerowicz, A., Arbaugh, M., Riebau, A. and Andersen, C., Eds., Developments in Environmental Science, Elsevier, Amsterdam, 79-107.

[12] Yokelson, R.J., Susott, R., Ward, D.E., Reardon, J. and Griffith, D.W.T. (1997) Emissions from Smoldering Combustion of Biomass Measured by Open Path Fourier Transform Infrared Spectroscopy. Journal of Geophysical Research, 102, 18865-18877. https://doi.org/10.1029/97JD00852

[13] Ohlemiller, T.J. (2002) Smouldering Combustion. In: DiNenno, P.J., Drysdale, D., Beyler, C.L., and Walton, W.D., Eds., SFPE Handbook of Fire Protection Engineering, 3rd Edition, National Fire Protection, Quincy.

[14] Lee, S., Baumann, K., Schauer, J.J., Sheesley, R.J., Naeher, L.P., Meinardi, S., Blake, D.R., Edgerton, E.S., Russell, A.G. and Clements, M. (2005) Gaseous and Particulate Emissions from Prescribed Burning in Georgia. Environmental Science \& Technology, 39, 9049-9056. https://doi.org/10.1021/es0515831

[15] Robinson, M.S., Zhao, M., Zack, L., Brindley, C., Portz, L., Quarterman, M., Long, X. and Herckes, P. (2011) Characterization of PM Collected during Broadcast and Slash-Pile Prescribed Burns of Predominately Ponderosa Pine Forests in Northern Arizona. Atmospheric Environment, 45, 2087-2094. https://doi.org/10.1016/j.atmosenv.2011.01.051

[16] Core, J.E., Cooper, J.A. and Neulicht, R.M. (1984) Current and Projected Impacts of Residential Wood Combustion on Pacific Northwest Air Quality. Journal of the Air Pollution Control Association, 34, 138-143. https://doi.org/10.1080/00022470.1984.10465735

[17] Core, J.E., Cooper, J.A., DeCesar, R.T. and Houck, J.E. (1982) Residential Wood Combustion Study. EPA 910/9-9-82-089a.

[18] Dokas, I., Statheropoulos, M. and Karma, S. (2007) Integration of Field Chemical Data in Initial Risk Assessment of Forest Fire Smoke. Science of the Total Environment, 376, 72-85. https://doi.org/10.1016/j.scitotenv.2007.01.064

[19] Reisen, F. and Brown, S.K. (2006) Implications for Community Health from Exposure to Bushfire Air Toxics. Environmental Chemistry, 3, 235-243. https://doi.org/10.1071/EN06008

[20] Stefanidou, M., Athanaselis, S. and Spiliopoulou, C. (2008) Health Impacts of Fire Smoke Inhalation. Inhalation Toxicology, 20, 761-766. https://doi.org/10.1080/08958370801975311

[21] Norris, J.C. and Ballantyne, B. (1993) Combustion Toxicology. In: Ballantyne, B., Mars, T. and Turner, P., Eds., General and Applied Toxicology, Vol. 3, MacMillan, London, 13091327.

[22] Reid, J.S., Koppmann, R., Eck, T.F. and Eleuterio, D.P. (2005) A Review of Biomass Burning Emissions Part II: Intensive Physical Properties of Biomass Burning Particles. Atmospheric Chemistry and Physics, 5, 799-825. https://doi.org/10.5194/acp-5-799-2005

[23] Brauer, M. (1998) Health Impact of Biomass Air Pollution. Report Prepared for the Bioregional Workshop on Health Impacts of Haze-Related Air Pollution. Kuala Lumpur, Malaysia.

[24] Ward, D.E. and Hardy, C. (1989) Organic and Elemental Profiles for Smoke from Pre- 
scribed Fires. In: Watson, J.G., Chow, J.C. and Mathai, C.V. Eds., Receptor Models in Air Resources Management. Transactions of an International Specialty Conference, Air and Waste Management Association, San Francisco, 299-321.

[25] CEPA (Canadian Environmental Protection Act) (1999) National Ambient Air Quality Objectives of Particulate Matter. Part 1, Science Assessment Document. Minister of Public Works and Government Services.

[26] Morawska, L. and Zhang, J. (2002) Combustion Sources of Particles. 1. Health Relevance and Source Signatures. Chemosphere, 49, 1045-1058. https://doi.org/10.1016/S0045-6535(02)00241-2

[27] Ward, D.E. (1997) Review of Smoke Components. Health Hazards of Smoke.

[28] Ottmar, R.D. (2001) Smoke Source Characteristics. In: Hardy, C.C., Ottmar, R.D., Peterson, J.L., Core, J.E. and Seamon, P., Eds., Smoke Management Guide for Prescribed and Wildland Fire, National Wildfire Coordination Group, Fire Use Working Team, Boise, 89-105.

[29] Johnson, R. (1999) Guidance on Measures in Forest Fire Emergency Cases. In: Goh, K-T., Schwela, D., Goldammer, J.G. and Simpson, O., Eds., Health Guidelines for Vegetation Fire Events-Background Papers, WHO/UNEP/WMO, Lima, 411-465.

[30] US EPA (Environmental Protection Agency) (1998) Fact Sheet, in EPA's Interim Air Quality Policy on Wildland and Prescribed Fires.

[31] Echalar, F., Gaudichet, A., Cachier, H. and Artaxo, P. (1995) Aerosol Emission by Tropical Forest and Savanna Biomass Burning: Characteristic Trace Elements and Fluxes. Geophysical Research Letters, 22, 3039-3042. https://doi.org/10.1029/95GL03170

[32] Butler, K.M. and Mulholland, G.M. (2004) Generation and Transport of Smoke Components. Fire Technology, 40, 149-176. https://doi.org/10.1023/B:FIRE.0000016841.07530.64

[33] Dockery, D.W. and Pope, C.A. (1994) Acute Respiratory Effects of Particulate Air Pollution. Annual Review of Public Health, 15, 107-132. https://doi.org/10.1146/annurev.pu.15.050194.000543

[34] Churg, A., Gilks, B. and Dai, J. (1999) Induction of Fibrogenic Mediators by Fine and Ultrafine Titanium Dioxide in Rat Tracheal Explants. American Journal of Physiology, 277, L975-L982.

[35] Donaldson, K., Li, X.Y. and MacNee, W. (1998) Ultrafine (Nanometer) Particle Mediated Lung Injury. Journal of Aerosol Science, 29, 553-560. https://doi.org/10.1016/S0021-8502(97)00464-3

[36] Highwood, E.J. and Kinnersley, R.P. (2006) When Smoke Gets in Our Eyes: The Multiple Impacts of Atmospheric Black Carbon on Climate, Air Quality and Health. Environment International, 32, 560-566. https://doi.org/10.1016/j.envint.2005.12.003

[37] Knaapen, A.M., Borm, P.J.A., Albrecht, C. and Schins, R.P.F. (2004) Inhaled Particles and Lung Cancer: Part A. Mechanisms. International Journal of Cancer, 109, 799-809. https://doi.org/10.1002/ijc.11708

[38] Borm, P.J.A., Shins, R.P.F. and Albrecht, C. (2004) Inhaled Particles and Lung Cancer: Part B. Paradigms and Risk Assessment. International Journal of Cancer, 110, 3-14. https://doi.org/10.1002/ijc.20064

[39] Schins, R.P.F., Lightbody, J.H., Borm, P.J.A., Shi, T.M., Donaldson, K. and Stone, V. (2004) Inflammatory Effects of Coarse and Fine Particulate Matter in Relation to Chemical and Biological Constituents. Toxicology and Applied Pharmacology, 195, 1-11. https://doi.org/10.1016/j.taap.2003.10.002

[40] Wong, L.N., Aung, H.H., Lamé, M.W., Wegesser, T.C. and Wilson, D.W. (2011) Fine Particulate Matter from Urban Ambient and Wildfire Sources from California's San Joaquin 
Valley Initiate Differential Inflammatory, Oxidative Stress, and Xenobiotic Responses in Human Bronchial Epithelial Cells. Toxicology in Vitro, 25, 1895-1905. https://doi.org/10.1016/j.tiv.2011.06.001

[41] Popp, C. J., Martin, R. S., Huang, S. and Arimoto, R. (2000) Atmospheric Effects of Large Fires: Spring 2000 Cerro Grande, NM (Los Alamos) Fire. A Millennium Symposium on Atmospheric Chemistry: Past, Present, and Future of Atmospheric Chemistry, 48, 81.

[42] Larson, T. and Koenig, J. (1994) Wood Smoke: Emissions and Non-Cancer Respiratory Effects. Annual Review of Public Health, 15, 133-156. https://doi.org/10.1146/annurev.pu.15.050194.001025

[43] Dost, F.N. (1991) Acute Toxicology of Components of Vegetation Smoke. Reviews of Environmental Contamination and Toxicology, 119, 1-46. https://doi.org/10.1007/978-1-4612-3078-6_1

[44] De Vos, A.J., Reisen, F., Cook, A., Devine, B. and Weinstein, P. (2009) Respiratory Irritants in Australian Bushfire Smoke: Air Toxics Sampling in a Smoke Chamber and during Prescribed Burns. Archives of Environmental Contamination and Toxicology, 56, 380-388. https://doi.org/10.1007/s00244-008-9209-3

[45] Einhorn, I.N. (1975) Physiological and Toxicological Aspects of Smoke Produced during the Combustion of Polymetric Materials. Environmental Health Perspectives, 11, 163-189. https://doi.org/10.1289/ehp.7511163

[46] ATSDR (Agency for Toxic Substances and Disease Registry) (1999) Toxicological Profile for Formaldehyde. US Department of Health and Human Services, Atlanta.

[47] Binetti, R., Costamagna, F. and Marcello, I. (2006) Development of Carcinogenicity Classifications and Evaluations: The Case of Formaldehyde. Annali dell Istituto Superiore di Sanità, 42, 132-143.

[48] Ottmar, R.D. and Reinhart, T.R. (2001) Smoke Exposure among Fireline Personnel. In: Hardy, C.C., Ottmar, R.D., Peterson, J.L., Core, J.E. and Seamon, P., Eds., Smoke Management Guide for Prescribed and Wildland Fire, National Wildfire Coordination Group, Fire Use Working Team, Boise, 51-57.

[49] IARC (International Agency for Research on Cancer) (2006) Formaldehyde. 2-Butoxyethanol and 1-Tert-Butoxypropan-2-Ol. IARC Monographs on the Evaluation of Carcinogenic Risks to Humans, 88.

[50] Kane, L.E. and Alarie, Y. (1977) Sensory Irritation to Formaldehyde and Acrolein during Single and Repeated Exposures in Mice. American Industrial Hygiene Association Journal, 38, 509-522. https://doi.org/10.1080/0002889778507665

[51] Ward, D.E. (1999) Smoke from Wildland Fires. In: Goh, K-T., Schwela, D., Goldammer, J.G. and Simpson, O., Eds., Health Guidelines for Vegetation Fire Events-Background Papers, WHO, Singapore, 70-85.

[52] Roberts J.M., Veresa, P.R., Cochranc, A.K., Warnekea, C., Burling, I.R., Yokelson, R.J., Lernera, B., Gilman, J.B., Kustera, W.C., Fall, R. and de Gouw, J. (2011) Isocyanic Acid in the Atmosphere and Its Possible Link to Smoke-Related Health Effects. Proceedings of the National Academy of Sciences of the United States of America, 108, 8966-8971. https://doi.org/10.1073/pnas.1103352108

[53] Booze, T.F., Reinhardt, T.E., Quiring, S.J. and Ottmar, R.D. (2004) A Screening-Level Assessment of Health Risks of Chronic Smoke Exposure for Wildland Fire-Fighters. Journal of Occupational and Environmental Hygiene, 1, 296-305. https://doi.org/10.1080/15459620490442500

[54] Kunii, O., Kanagawa, S., Yajima, I., Hisamatsu, Y., Yamamura, S., Amagai, T. and Ismail, I. 
T.S. (2002) The 1997 Haze Disaster in Indonesia: Its Air Quality and Health Effects. Archives of Environmental Health, 57, 16-22. https://doi.org/10.1080/00039890209602912

[55] Jenkins, B.M., Jones, A.D., Turn, S.Q. and Williams, R.B. (1996) Emission Factors for Polycyclic Aromatic Hydrocarbons from Biomass Burning. Environmental Science \& Technology, 30, 2462-2469. https://doi.org/10.1021/es950699m

[56] Jenkins, B.M., Jones, A.D., Turn, S.Q. and Williams, R.B. (1996) Particle Concentrations, Gas-Particle Partitioning, and Species Correlations for Polycyclic Aromatic Hydrocarbons (PAH) Emitted during Biomass Burning. Atmospheric Environment, 30, 3825-3835. https://doi.org/10.1016/1352-2310(96)00084-2

[57] McMahon, C.K. and Tsoukalas, S. (1978) Polynuclear Aromatic Hydrocarbons in Forest Fire Smoke. In: Jones, P.W. and Freudenthal, R.I., Eds. Carcinogenesis, Vol. 3: Polynuclear Aromatic Hydrocarbons, Raven Press, New York, 61-72.

[58] Fang, M., Zheng, M., Wang, F., To, K.L., Jaafar, A.B. and Tong, S.L. (1999) The SolventExtractable Organic Compounds in the Indonesia Biomass Burning Aerosols-Characterization Studies. Atmospheric Environment, 33, 783-795.

https://doi.org/10.1016/S1352-2310(98)00210-6

[59] Adam, H., Hunter, D. and Trichopoulos, D. (2002) Textbook of Cancer Epidemiology. Oxford University Press, Oxford.

[60] Langmann, B., Duncan, B., Textor, C., Trentmannd, J. and van der Werf, G.R. (2009) Vegetation Fire Emissions and Their Impact on Air Pollution and Climate. Atmospheric Environment, 43, 107-116. https://doi.org/10.1016/j.atmosenv.2008.09.047

[61] Hartzell, G.E. (1996) Overview of Combustion Toxicology. Toxicology, 115, 7-23. https://doi.org/10.1016/S0300-483X(96)03492-0

[62] Norris, J.C. and Ballantyne, B. (1999) Toxicology and Implications of the Products of Combustion. In: Ballantyne, B., Marrs, T. and Syversen, T.L.M., Eds., General and Applied Toxicology, 2nd Edition, Macmilan Reference Ltd, London, 1915-1933.

[63] Evans, G.W. and Kantrowitz, E. (2002) Socioeconomic Status and Health: The Potential Role of Environmental Risk Exposure. Annual Review of Public Health, 23, 303-331. https://doi.org/10.1146/annurev.publhealth.23.112001.112349

[64] Lacaux, J.P., Delmas, R., Jambert, C. and Kuhlbusch, T.A.J. (1996) $\mathrm{NO}_{x}$ Emissions from African Savanna Fires. Journal of Geophysical Research: Atmospheres, 101, 23585-23596. https://doi.org/10.1029/96JD01624

[65] Griffith, D.W.T., Mankin, W.G., Coffey, M.T., Ward, D.E. and Riebau, A. (1991) FTIR Remote Sensing of Biomass Burning Emissions of $\mathrm{CO}_{2}, \mathrm{CO}, \mathrm{CH}_{4}, \mathrm{CH}_{2} \mathrm{O}, \mathrm{NO}, \mathrm{NO}_{2}, \mathrm{NH}_{3}$, and $\mathrm{N}_{2} \mathrm{O}$. In: Levine, J.S., Ed., Global Biomass Burning. Atmospheric, Climatic and Biospheric Implications, MIT Press, Cambridge, 230-239.

[66] Hogue, C. (2005) No Vote for US in Chemicals Treaty. Chemical and Engineering News, 83, 26-27. https://doi.org/10.1021/cen-v083n018.p026

[67] Mueller, S.F. and Mallard, J.W. (2011) Contributions of Natural Emissions to Ozone and PM2.5 as Simulated by the Community Multiscale Air Quality (CMAQ) Model. Environmental Science \& Technology, 45, 4817-4823. https://doi.org/10.1021/es103645m

[68] Bertschi, I.T. and Jaffe, D.A. (2005) Long-Range Transport of Ozone, Carbon Monoxide, and Aerosols in the NE Pacific Troposphere during the Summer of 2003: Observations of Smoke Plumes from Asian Boreal Fires. Journal of Geophysical Research, 110, Article ID: D05303. https://doi.org/10.1029/2004jd005135

[69] Wotawa, G. and Trainer, M. (2000) The Influence of Canadian Forest Fires on Pollutant Concentrations in the United States. Science, 288, 324-328. 
https://doi.org/10.1126/science.288.5464.324

[70] Stith J.L., Radke, F.L. and Hobbs, R.V. (1981) Particle Emissions and the Production of Ozone and Nitrogen Oxides from the Burning of Forest Slash. Atmospheric Environment, 7, 73-82. https://doi.org/10.1016/0004-6981(81)90127-X

[71] Delany, A., Haagensen, P., Walters, S., Wartburg, A.F. and Crutzen, P.J. (1985) Photochemically Produced Ozone in the Emission from Large-Scale Tropical Vegetation Fires. Journal of Geophysical Research, 90, 2425-2429. https://doi.org/10.1029/JD090iD01p02425

[72] McMahon, C.K. and Bush, P.B. (1992) Forest Worker Exposure to Airborne Herbicide Residues in Smoke from Prescribed Fires in the Southern United States. American Industrial Hygiene Association, 53, 265-272. https://doi.org/10.1080/15298669291359636

[73] Abelson, P.H. (1994) Sources of Dioxin (Response to Letter). Science, 266, 349-352. https://doi.org/10.1126/science.7939671

[74] Mukerjee, D. (1997) Health Impact of Polychlorinated Dibenzo-P-Dioxins. Journal of the Air \& Waste Management Association, 48, 157-165. https://doi.org/10.1080/10473289.1998.10463655

[75] Ward, T.J. and Smith, G.C. (2001) Air Sampling Study of the 2000 Montana Wildfire Season. University of Montana, Missoula.

[76] Reh, C.M. and Deitchman, S.D. (1992) US Department of the Interior National Park Service. Health Hazard Evaluation Report, Heta 88-320-2176, NIOSH. http://www.cdc.gov/niosh/hhe/reports/pdfs/1988-0320-2176.pdf

[77] Lobert, J.M., Scharffe, D.H., Hao, W.-M., Kuhlbusch, T.A., Seuwen, R., Wameck, P. and Cmtzen, P.J. (1991) Experimental Evaluation of Biomass Burning Emissions: Nitrogen, and Carbon Containing Compounds. In: Levine, J.S., Ed., Global Biomass Burning. Atmospheric, Climatic and Biospheric Implications, MIT Press, Cambridge, 289-304.

[78] Le Canut, P., Andreae, M.O., Harris, G.W., Wienhold, F.G. and Zenker, T. (1996) Airborne Studies of Emissions from Savanna Fires in Southern Africa, 1, Aerosol Emissions Measured with a Laser Optical Particle Counter. Journal of Geophysical Research, 101, 2361523630. https://doi.org/10.1029/95JD02610

[79] Delmas, R., Lacaux, J.P. and Brocard, D. (1995) Determination of Biomass Burning Emission Factors: Methods and Results. Environmental Monitoring and Assessment, 38, 181204. https://doi.org/10.1007/BF00546762

[80] Statheropoulos, M. and Karma, S. (2007) Complexity and Origin of the Smoke Components as Measured near the Flame-Front of a Real Forest Fire Incident: A Case Study. Journal of Analytical and Applied Pyrolysis, 78, 430-437. https://doi.org/10.1016/j.jaap.2006.10.011

[81] Mott, J.A., Mannino, D.M., Alverson, C.J., Kiyu, A., Hashim, J., Lee, T., Falter, K. and Redd, S.C. (2005) Cardiorespiratory Hospitalizations Associated with Smoke Exposure during the 1997 Southeast Asian Forest Fires. International Journal of Hygiene and Environmental Health, 208, 75-85. https://doi.org/10.1016/j.ijheh.2005.01.018

[82] Artaxo, P.G.F., Yamasoe, M.A. and Martins, J. (1994) Fine Mode Aerosol Composition at Three Long-Term Atmospheric Monitoring Sites in the Amazon Basin. Journal of Geophysical Research, 99, 22857-22868. https://doi.org/10.1029/94JD01023

[83] Vedal, S. and Dutton, S. (2006) Wildfire Air Pollution and Daily Mortality in A Large Urban Area. Environmental Research, 102, 29-35. https://doi.org/10.1016/j.envres.2006.03.008

[84] Smith, M.A., Jalaludin, B., Byles, J.E., Lim, L. and Leeder, S.R. (1996) Asthma Presentations to Emergency Departments in Western Sydney during the January 1994 Bushfires. International Journal of Epidemiology, 25, 1227-1236. https://doi.org/10.1093/ije/25.6.1227

[85] Phonboon, K., Paisarn-uchapong, O., Kanatharana, P. and Agsron, S. (1999) Smoke Epi- 
sodes Emissions Characterization and Assessment of Health Risks Related to Downwind Air Quality_Case Study, Thailand. In: In: Goh, K-T., Schwela, D., Goldammer, J.G. and Simpson, O., Eds., Health Guidelines for Vegetation Fire Events: Background Papers, World Health Organization, Geneva, 334-380.

[86] Phuleria, H.C., Fine, P.M., Zhu, Y.F. and Sioutas, C. (2005) Air Quality Impacts of the October 2003 Southern California Wildfires. Journal of Geophysical Research: Atmospheres, 110, Article ID: D07S20. https://doi.org/10.1029/2004JD004626

[87] Jalaludin, B., Smith, M., O’Toole, B. and Leeder, S. (2000) Acute Effects of Bushfires on Peak Expiratory Flow Rates in Children with Wheeze: A Time Series Analysis. Australian and New Zealand Journal of Public Health, 24, 174-177. https://doi.org/10.1111/j.1467-842X.2000.tb00138.x

[88] Duclos, P., Sanderson, L.M. and Lipsett, M. (1990) The 1987 Forest Fire Disaster in California-Assessment of Emergency Room Visits. Archives of Environmental Health, 45, 53-58. https://doi.org/10.1080/00039896.1990.9935925

[89] Radojevic, M. (2003) Haze Research in Brunei Darussalam during the 1998 Episode. Pure and Applied Geophysics, 160, 251-264. https://doi.org/10.1007/s00024-003-8776-5

[90] Emmanuel, S.C. (2000) Impact to Lung Health of Haze from Forest Fires: The Singapore Experience. Respirology, 5, 175-182. https://doi.org/10.1046/j.1440-1843.2000.00247.x

[91] Chew, F.T., Ooi, B.C., Hui, J.K.S., Saharom, R., Goh, D.Y.T. and Lee, B.W. (1995) Singapore Haze and Acute Asthma in Children. Lancet, 346, 1427-1427. https://doi.org/10.1016/S0140-6736(95)92443-4

[92] Johnston, F.H., Bailie, R.S., Pilotto, L.S. and Hanigan, I.C. (2007) Ambient Biomass Smoke and Cardio-Respiratory Hospital Admissions in Darwin, Australia. BMC Public Health, 7, 240. https://doi.org/10.1186/1471-2458-7-240

[93] Miranda A.I., Ferreira, J., Valente, J., Santos, P., Amorim, J.H. and Borrego, C. (2005) Smoke Measurements during Gestosa-2002 Experimental Field Fires. International Journal of Wildland Fire, 14, 107-116. https://doi.org/10.1071/WF04069

[94] Sapkota, A., Symons, J.M., Kleissl, J., Wang, L., Parlange, M.B., Ondov, J., Breysse, P.N., Diette, G.B., Eggleston, P.A. and Buckley, T.J. (2005) Impact of the 2002 Canadian Forest Fires on Particulate Matter Air Quality in Baltimore City. Environmental Science \& Technology, 39, 24-32. https://doi.org/10.1021/es035311z

[95] Johnston, F.H., Kavanagh, A.M., Bowman, D.M.J.S. and Scott, R.K. (2002) Exposure to Bushfire Smoke and Asthma: An Ecological Study. Medical Journal of Australia, 176, 535538.

[96] Delfino, R., Brummel, S., Wu, J., Stern, H., Ostro, B., Lipsett, M., Winer, A., Street, D.H., Zhang, L., Tioa, T. and Gillen, D. (2009) The Relationship of Respiratory and Cardiovascular Hospital Admissions to the Southern California Wildfires of 2003. Occupational and Environmental Medicine, 66, 189-197. https://doi.org/10.1136/oem.2008.041376

[97] Sutherland, E.R., Make, B.J., Vedal, S., Zhang, L.N., Dutton, S.J., Murphy, J.R. and Silkoff, P.E. (2005) Wildfire Smoke and Respiratory Symptoms in Patients with Chronic Obstructive Pulmonary Disease. Journal of Allergy and Clinical Immunology, 115, 420-422. https://doi.org/10.1016/j.jaci.2004.11.030

[98] Materna, B., Jones, J.R., Sutton, P.M., Rothman, N. and Harrison, R.J. (1992) Occupational Exposures in California Wildland fire Fighting. American Industrial Hygiene Association Journal, 53, 69-76. https://doi.org/10.1080/15298669291359311

[99] Pinto, J.P. and Grant, L.D. (1999) Approaches to Monitoring of Air Pollutants and Evaluation of Health Impacts Produced by Biomass Burning. In: Goh, K-T., Schwela, D., Gol- 
dammer, J.G. and Simpson, O., Eds., Health Guidelines for Vegetation Fire Events-Background Papers, WHO/UNEP/WMO, Lima, 147-185.

[100] Reinhardt, T.E., Ottmar, R.D. and Hanneman, A.J.S. (2000) Smoke Exposure among Firefighters at Prescribed Burns in the Pacific Northwest. Res. Pap. PNW-RP-526, US Department of Agriculture, Forest Service, Pacific Northwest. Research Station, Portland, 45 p.

[101] Reinhardt, T. and Ottmar, R. (1997) Smoke Exposure among Wildland Firefighters: A Review and Discussion of Current Literature. United States Department of Agriculture, Forest Service, Pacific Northwest Research Station. https://doi.org/10.2737/PNW-GTR-373

[102] US EPA (Environmental Protection Agency) (1982) Compilation of Air Emission Factors. US Environmental Protection Agency, AP-42, EP 4.9:42/985.

[103] Ward, D.E. (1990) Factors Influencing the Emissions of Gases and Particulate Matter from Biomass Burning. In: Goldammer, J.G., Ed., Fire in the Tropical Biota: Ecosystem Processes and Global Challenges, Ecological Studies, Springer, Berlin, 418-436.

https://doi.org/10.1007/978-3-642-75395-4_18

[104] Heil A. (1998) Polycyclic Aromatic Hydrocarbons (PAHs) in the Haze from Forest Fires in Indonesia 1997. Ministry of Forestry and Estate Crops of Indonesia. http://www.fire.uni-freiburg.de/se_asia/projects/pahs.html

[105] Friedli, H.R., Atlas, E., Stroud, V.R., Giovanni, L., Campos, T. and Radke, L.F. (2001) Volatile Organic Trace Gases Emitted from North American Wildfires. Global Biogeochemical Cycles, 15, 435-452. https://doi.org/10.1029/2000GB001328

[106] Tansey, K., Gregoire, J., Defourny, P., Leigh, R., Pekel, J., van Bochove, E. and Bartholome, E. (2008) A New, Global, Multi-Annual (2000-2007) Burnt Area Product at $1 \mathrm{~km}$ Resolution and Daily Intervals. Geophysical Research Letters, 35, Article ID: L01401. https://doi.org/10.1029/2007GL031567

[107] Roy, D.P., Lin, Y., Lewis, E.P. and Justice, C.O. (2005) Prototyping a Global Algorithm for Systematic Fire Affected Area Mapping Using MODIS Time Series Data. Remote Sensing of Environment, 97, 137-162. https://doi.org/10.1016/j.rse.2005.04.007

[108] US EPA (Environmental Protection Agency) (2003) How Smoke from Fires Can Affect Your Health. Office of Air and Radiation, Washington DC. http://tinyurl.com/6jvn2k4

[109] US CDC (Centers for Disease Control and Prevention) (2007) Fact Sheet: Wildfires. Atlanta, GA.

[110] PEHSU (Pediatric Environmental Health Specialty Units) (2007) Health Risks of Wildfires for Children-Acute Phase. Washington DC. http://aoec.org/documents/positions/Wildfires_Acute_Phase.AAPapproved.pdf

[111] Bowman, D.M. and Johnston, F.H. (2005) Wildfire Smoke, Fire Management, and Human Health. EcoHealth, 2, 76-80. https://doi.org/10.1007/s10393-004-0149-8

[112] Rappold, A., Stone, S., Cascio, W., Neas, L., Kilaru, V., Carraway, M.S., Szykman, J.J., Ising, A., Cleve, W.E., Meredith, J.T., Vaughan-Batten, H., Deyneka, L. and Devlin, R.B. (2011) Peat Bog Wildfire Smoke Exposure in Rural North Carolina Is Associated with Cardiopulmonary Emergency Department Visits Assessed through Syndromic Surveillance. Environmental Health Perspectives, 119, 1415-1420. https://doi.org/10.1289/ehp.1003206

[113] Henderson, S.B., Brauer, M., MacNab, Y.C. and Kennedy, S.M. (2011) Three Measures of Forest Fire Smoke Exposure and Their Associations with Respiratory and Cardiovascular Health Outcomes in a Population-Based Cohort. Environmental Health Perspectives, 119, 1266-1271. https://doi.org/10.1289/ehp.1002288

[114] Barregard, L., Sällsten, G., Gustafson, P., Andersson, L., Johansson L., Basu, S. and Stigendal, L. (2006) Experimental Exposure to Wood-Smoke Particles in Healthy Humans: Effects 
on Markers of Inflammation, Coagulation, and Lipid Peroxidation. Inhalation Toxicology, 18, 845-853. https://doi.org/10.1080/08958370600685798

[115] Tan, W.C., Qiu, D., Liam, B.L., Ng, T.P., Lee, S.H., van Eeden, S.F., D’Yachkova, Y. and Hogg, J.C. (2000) The Human Bone Marrow Response to Acute Air Pollution Caused by Forest Fires. American Journal of Respiratory and Critical Care Medicine, 161, 1213-1217. https://doi.org/10.1164/ajrccm.161.4.9904084

[116] Chia, H.P., Chia, K.S., Ooi, P.L., Ng, T.P., Goh, K.T. and Lee, H.P. (1995) Effects of the Recent Haze in Singapore on the Frequency of Attacks among Group of Known Asthmatics. In: Goh, K.T.and Ooi, P.L., Eds., Health and the Built Environment, Institute of Environmental Epidemiology, Singapore, 87-93.

[117] Ostermann, K. and Brauer, M. (2000) Air Quality Haze Episodes and Its Impact on Health. USDA Forest Service, Southern Research Station, Asheville.

[118] Hu, G., Zhou, Y., Tian, J., Yao, W., Li, J., Li, B. and Ran, P. (2010) Risk of COPD from Exposure to Biomass Smoke: A Meta Analysis. Chest, 138, 20-31.

https://doi.org/10.1378/chest.08-2114

[119] Mott, J.A., Meyer, P., Mannino, D., Redd, S.C., Smith, E.M., Gotway-Crawford, C. and Chase, E. (2002) Wildland Forest Fire Smoke: Health Effects and Intervention Evaluation, Hoopa, California, 1999. Western Journal of Medicine, 176, 157-162. https://doi.org/10.1136/ewjm.176.3.157

[120] Awang, M.B., Jaafar, A.B., Abdullah, A.M., Ismail, M.B., Hassan, M.N., Abdullah, R., Johan, S. and Noor, H. (2000) Air Quality in Malaysia: Impacts, Management Issues and Future Challenges. Respirology, 5, 183-196. https://doi.org/10.1046/j.1440-1843.2000.00248.x

[121] Brauer, M. and Hisham-Hashim, J. (1998) FIRES in Indonesia: Crisis and Reaction. Environmental Science \& Technology, 32, 404a-407a. https://doi.org/10.1021/es983677j

[122] Hisham-Hashim, J., Hashim, Z., Jalaludin, J., Lubis, S. and Hashim, R. (1998) Respiratory Function of Elementary School Children Exposed to the 1997 Kuala Lumpur Haze. Epidemiology, 9, S103. https://doi.org/10.1097/00001648-199807001-00330

[123] Koenig, J., Larson, T.V., Hanley, Q.S., Rebolledo, V., Dumler, K., Checkoway, H., Wang, S. Z., Lin, D. and Pierson, W.E. (1993) Pulmonary Function Changes in Children Associated with Fine Particulate Matter. Environmental Research, 63, 26-388. https://doi.org/10.1006/enrs.1993.1123

[124] Johnson, K., Gideon, R. and Loftsgaarden, D.O. (1990) Montana Air Pollution Study: Children'S Health Effects. Journal of Official Statistics, 5, 391-408.

[125] Frankenberg, E., McKee, D. and Thomas, D. (2002) Health Consequences of Forest Fires in Indonesia. IUSSP Regional Population Conference, Bangkok, 10-13 June 2002.

[126] Aditama, T.Y. (2000) Impact of Haze from Forest Fire to Respiratory Health: Indonesian Experience. Respirology, 5, 169-174. https://doi.org/10.1046/j.1440-1843.2000.00246.x

[127] Kunii, O. (1999) Basic Facts-Determining Downwind Exposures and Their Associated Health Effects, Assessment of Health Effects in Practice: A Case Study in the 1997 Forest Fires in Indonesia. In: Goh, K-T., Schwela, D., Goldammer, J.G. and Simpson, O., Eds., Health Guidelines for Vegetation Fire Events-Background Papers, World Health Organization, Geneva, 295-312.

[128] US CDC (Centers for Disease Control and Prevention) (1999) Surveillance of Morbidity during Wildfires-Central Florida, 1998. Morbidity and Mortality Weekly Report, 48, 7879.

[129] Lipsett, M., Hurley, S. and Ostro, B. (1997) Air Pollution and Emergency Room Visits for Asthma in Santa Clara County, California. Environmental Health Perspectives, 105, 216 - 


\section{2. https://doi.org/10.1289/ehp.97105216}

[130] Schwartz, J., Slater, D., Larson, T.V., Pierson, W.E. and Koenig, J.Q. (1993) Particulate Air Pollution and Hospital Emergency Room Visits for Asthma in Seattle. American Review of Respiratory Diseases, 147, 826-831. https://doi.org/10.1164/ajrccm/147.4.826

[131] Patz, J.A., Engelberg, D. and Last, J. (2000) The Effects of Changing Weather on Public Health. Annual Review of Public Health, 21, 271-307. https://doi.org/10.1146/annurev.publhealth.21.1.271

[132] Hannigan, I., Johnston, F. and Morgan, G. (2008) Vegetation Fire Smoke, Indigenous Status and Cardio-Respiratory Hospital Admissions in Darwin, Australia, 1996-2005: A TimeSeries Study. Environmental Health, 7, 42. https://doi.org/10.1186/1476-069X-7-42

[133] Long, W., Tate, R.B., Neuman, M., Manfreda, J., Becker, A.B. and Anthonisen, N.R. (1998) Respiratory Symptoms in a Susceptible Population Due to Burning of Agricultural Residue. Chest, 113, 351-357. https://doi.org/10.1378/chest.113.2.351

[134] Shusterman, D., Kaplan, J.Z. and Canabarro, C. (1993) Immediate Health-Effects of an Urban Wildfire. Western Journal of Medicine, 158, 133-138.

[135] Swiston, J., Davidson, W., Attridge, S., Li, G., Brauer, M. and van Eeden, S. (2008) Wood Smoke Exposure Induces a Pulmonary and Systemic Inflammatory Response in Firefighters. European Respiratory Journal, 32, 129-138. https://doi.org/10.1183/09031936.00097707

[136] Betchley, C., Koenig, J.Q., Vanbelle, G., Checkoway, H. and Reinhardt, T. (1997) Pulmonary Function and Respiratory Symptoms in Forest Firefighters. American Journal of Industrial Medicine, 31, 503-509. https://doi.org/10.1002/(SICI)1097-0274(199705)31:5<503::AID-AJIM3>3.0.CO;2-U

[137] Reh, C.M., Letts, D. and Deitchman, S. (1994) Health Hazard Evaluation Report No. HETA-90-0365-2314. US Department of the Interior, National Park Service, Yosemite National Park, California.

[138] Liu, D., Tager, I.B., Balmes, J.R. and Harrison, R.J. (1992) The Effect of Smoke Inhalation on Lung Function and Airway Responsiveness in Wildland Fire Fighters. American Review of Respiratory Diseases, 146, 1469-1473. https://doi.org/10.1164/ajrccm/146.6.1469

[139] Letts, D., Fidler, A.T., Deitchman, S. and Reh, C.M. (1991) Health Hazard Evaluation Report No. HETA-91-152-2140. US Department of the Interior, National Park Service, Southern California, Hazard Evaluations and Technical Assistance Branch, NIOSH, US Department of Health and Human Services, Cincinnati, 24.

[140] Rothman, N., Ford, D., Baser, M.E., Hansen, J.A., O’Toole, T., Tockman, M.S. and Strickland, P.T. (1991) Pulmonary Function and Respiratory Symptoms in Wildland Firefighters. Journal of Occupational Medicine, 33, 1163-1167. https://doi.org/10.1097/00043764-199111000-00013

[141] NIOSH (National Institute for Occupational Safety and Health) (2004) A Summary of Health Hazard Evaluations: Issues Related to Occupational Exposure to fire Fighters 1990 to 2001. Publication No. 2004-115. http://www.cdc.gov/niosh/docs/2004-115/pdfs/2004-115.pdf

[142] Sutton, P., Castorina, J., Harrison, R. and Ford, D.P. (1988) Carbon Monoxide Exposure in Wildland Firefighters. Occupational Health Surveillance and Evaluation Program, Epidemiologic Studies and Surveillance Section, California Dept. of Health Services, Berkeley.

[143] Odihi, J.O. (2001) Haze and Health in Brunei Darussalam: The Case of the 1997-98 Episodes. Singapore Journal of Tropical Geography, 22, 38-51.

https://doi.org/10.1111/1467-9493.00092

[144] Muraleedharan, T.R., Radojevic, M., Waugh, A. and Caruana, A. (2000) Chemical Charac- 
terisation of the Haze in Brunei Darussalam during the 1998 Episode. Atmospheric Environment, 34, 2725-2731. https://doi.org/10.1016/S1352-2310(99)00341-6

[145] Schwartz, J. (1994) Air Pollution and Hospital Admissions for the Elderly in Birmingham, Alabama. American Journal of Epidemiology, 139, 589-598.

[146] From, L., Bergen, L. and Humlie, C.J. (1992) The Effects of Open Leaf Burning on Spirometric Measurements in Asthma. Chest, 101, 1236-1239.

https://doi.org/10.1378/chest.101.5.1236

[147] Vestin, A., Rissler, J., Swietlicki, E., Frank, G.P. and Andreae, M.O. (2007) Cloud-Nucleating Properties of the Amazonian Biomass Burning Aerosol: Cloud Condensation Nuclei Measurements and Modeling. Journal of Geophysical Research: Atmospheres, 112, Article ID: D14201. https://doi.org/10.1029/2006JD008104

[148] Lin, J.C., Matsui, T., Pielke, R.A. and Kummerow, C. (2006) Effects of Biomass-Burning Derived Aerosols on Precipitation and Clouds in the Amazon Basin: A Satellite Based Empirical Study. Journal of Geophysical Research: Atmospheres, 111, Article ID: D19204. https://doi.org/10.1029/2005jd006884

[149] Mazzoni, D., Logan, J. A., Diner, D., Kahn, R., Tong, L. and Li, Q. (2007) A data-mining approach to associating MISR smoke plume heights with MODIS fire measurements. $R e$ mote Sensing of Environment, 107, 138-148. https://doi.org/10.1016/j.rse.2006.08.014

[150] Labonne, M., Breon, F.M. and Chevallier, F. (2007) Injection Height of Biomass Burning Aerosols as Seen from a Spaceborne Lidar. Geophysical Research Letters, 34, Article ID: L11806. https://doi.org/10.1029/2007gl029311

[151] Fromm, M.D. and Servranckx, R. (2003) Transport of Forest Fire Smoke above the Tropopause by Supercell Convection. Geophysical Research Letters, 30, 1542-1545. https://doi.org/10.1029/2002GL016820

[152] Luderer, G., Trentmann, J., Winterrath, T., Textor, C., Herzog, M., Graf, H.F. and Andreae, M.O. (2006) Modeling of Biomass Smoke Injection into the Lower Stratosphere by a Large Forest Fire (Part II): Sensitivity Studies. Atmospheric Chemistry and Physics, 6, 5261-5277. https://doi.org/10.5194/acp-6-5261-2006

[153] Podgorny, I.A., Li, F. and Rammanathan, V. (2003) Large Aerosol Radiative Forcing Due to the 1997 Indonesian Forest Fire. Geophysical Research Letters, 30, 1028. https://doi.org/10.1029/2002GL015979

[154] Burke, M.P., Hogue, T.S., Ferreira, M., Mendez, C.B., Navarro, B., Lopez, S. and Jay, J.A. (2010) The Effect of Wildfire on Soil Mercury Concentrations in Southern California Watersheds. Water Air \& Soil Pollution, 212, 369-385. https://doi.org/10.1007/s11270-010-0351-y

[155] Ferguson, S.A., Peterson, J. and Acheson, A. (2001) Automated, Real-Time Predictions of Cumulative Smoke Impacts from Prescribed Forest and Agricultural Fires. 4th Symposium on Fire and Forest Meteorology, Reno, 13-15 November 2001, 168-175.

[156] Lentile, L.B., Holden, Z.A., Smith, A.M.S., Falkowski, M.J., Hudak, A.T., Morgan, P., Lewis, S.A., Gessler, P.E. and Benson, N.C. (2006) Remote Sensing Techniques to Assess Active Fire Characteristics and Post-Fire Effects. International Journal of Wildland Fire, 15, 319345. https://doi.org/10.1071/WF05097

[157] Hoelzemann, J.J., Schultz, M.G., Brasseur, G.P., Granier, C. and Simon, M. (2004) Global Wildland Fire Emission Model (GWEM): Evaluating the Use of Global Area Burnt Satellite Data. Journal of Geophysical Research, 109, Article ID: D14S04. https://doi.org/10.1029/2003jd003666

[158] Ito, A. and Penner, J.E. (2004) Global Estimates of Biomass Burning Emissions Based on 
Satellite Imagery for the Year 2000. Journal of Geophysical Research, 109, Article ID: D14S05. https://doi.org/10.1029/2003jd004423

[159] Lipsett, M. and Materna, B. (2008) Wildfire Smoke: A Guide for Public Health Officials. Office of Environmental Health Hazard Assessment.

[160] Manitoba health. (2012) Smoke Exposure from Wildland Fires. Interim Guidelines for Protecting Community Health and Wellbeing.

http://www.gov.mb.ca/health/publichealth/wildlandfiresmokeexposure.pdf

[161] US EPA (Environmental Protection Agency) (2001) Wildfire Smoke: A Guide for Public Health Officials. http://www.epa.gov/ttn/amtic/files/ambient/smoke/wildgd.pdf

Submit or recommend next manuscript to SCIRP and we will provide best service for you:

Accepting pre-submission inquiries through Email, Facebook, LinkedIn, Twitter, etc.

A wide selection of journals (inclusive of 9 subjects, more than 200 journals)

Providing 24-hour high-quality service

User-friendly online submission system

Fair and swift peer-review system

Efficient typesetting and proofreading procedure

Display of the result of downloads and visits, as well as the number of cited articles

Maximum dissemination of your research work

Submit your manuscript at: http://papersubmission.scirp.org/

Or contact jep@scirp.org 